\title{
The Properties of Extracellular Enzymes of Venturia inaequalis and Their Association with Loss of Virulence of the Fungus in Culture
}

\author{
By R. C. HIGNETT, A. L. ROBERTS AND J. H. CARDER \\ East Malling Research Station, Maidstone, Kent ME19 6BJ
}

(Received 28 April 1978; revised 8 August 1978)

\begin{abstract}
Ribonuclease, deoxyribonuclease, acid phosphatase and phenoloxidase were detected in preparations of extracellular melanoprotein isolated from cultures of Venturia inaequalis. The high initial levels of activity produced per $\mathrm{g}$ fungus declined within a few days of inoculation, to an approximately constant level. About six times as much activity was released by conidia germinating in medium enriched with wood extract than was released in basal medium. After $5 \mathrm{~d}$ incubation, the rate of production of enzymically active melanoprotein reflected the rate of growth of the fungus. Isolated melanoprotein stored at $4{ }^{\circ} \mathrm{C}$ for 3 months showed up to $190 \%$ more hydrolase activity than was measured originally, but longer storage caused a subsequent decrease in activity. Only phenoloxidase decreased continuously during storage. The apparent stability of the bond between melanin and protein under dissociating conditions contrasted with the reversible formation of complexes between the fungal product and polyelectrolytes.

A set of re-isolates of different ages produced randomly variable levels of hydrolase activity when cultured repeatedly over a period of 16 months. On each occasion, however, the specific and total activity of each hydrolase was (with one marginal exception) lower in cultures of the oldest re-isolate than in those of the later re-isolates. In contrast, the specific activity of phenoloxidase was highest in cultures of the oldest re-isolate. These changes were associated with the decline in virulence observed in stored re-isolates of clone $\mathrm{E}_{1}$ of $V$. inaequalis.
\end{abstract}

\section{INTRODUCTION}

Extracellular enzymes associated with melanoprotein produced by cultures of Venturia inaequalis were studied with a view to elucidating the biological stability of the pathogen. An attempt was also made to correlate the various levels of enzyme activity produced in culture by different clones with the corresponding levels of virulence observed on test plants.

\section{METHODS}

Growth of $V$. inaequalis and preparation of extracellular melanoproteins. Stock cultures of each isolate were maintained under paraffin oil at $4{ }^{\circ} \mathrm{C}$ (Kirkham, 1957). Using the methods of Hignett et al. (1977), extracellular melanoprotein was isolated from $40 \mathrm{ml}$ shake cultures of $V$. inaequalis and fractionally precipitated with ethyl alcohol giving two fractions (N50 and N75). The cultures were usually grown on basal medium augmented with diffusible neutral wood extract (NWED) (Hignett et al., 1977). For cultures grown on basal medium without NWED, $0.05 \%(\mathrm{w} / \mathrm{v})$ asparagine was added as an alternative nitrogen source. Growth curves were obtained by taking duplicate $40 \mathrm{ml}$ shake cultures at intervals up to $18 \mathrm{~d}$ after inoculation. The mycelium was filtered off, washed exhaustively and dried to constant weight over phosphorus pentoxide. Non-diffusible material in the culture fluid was isolated by dialysis at $4{ }^{\circ} \mathrm{C}$ against five changes of 11 water 
over a period of $72 \mathrm{~h}$ and estimated (without further purification) by drying samples to constant weight at $105^{\circ} \mathrm{C}$. Omission of the alcohol precipitation step left a small proportion of polymerized phenolic material from the culture fluid in the non-diffusible melanoprotein preparation. This was tolerated in some experiments to minimize handling losses.

Gel electrophoresis and gel filtration. Polyacrylamide gel electrophoresis was carried out on $5 \%(\mathrm{w} / \mathrm{v})$ $0.5 \times 6 \mathrm{~cm}$ gel rods (Cyanogum 41; BDH) made up in 1\% (w/v) Ampholine (LKB). After polymerization with 2-dimethylaminoethyl cyanide $(\mathrm{BDH})(0.2 \%, \mathrm{v} / \mathrm{v})$ and ammonium persulphate $(0.2 \%, \mathrm{w} / \mathrm{v})$, the gels were pre-run at $5 \mathrm{~mA}$ each for $1 \mathrm{~h}$ to remove persulphate before use. The lower and upper electrolytes were $2 \mathrm{M}$-acetic acid and $3 \%$ (v/v) ethanolamine, respectively. The acid mixture of Stenman \& Gräsbeck (1972) was used as an alternative to Ampholine in the preparation of $\mathrm{pH}$ gradient gels. Measurements of $\mathrm{pH}$ were made on gel segments $(3 \mathrm{~mm}$ ) after maceration in $0.3 \mathrm{ml}$ water.

In some experiments, melanoprotein (pigment) solutions were mixed with solid urea to a final concentration of $8 \mathrm{~m}$ before electrophoresis. Gel filtration was done with $8 \mathrm{M}$-urea, $4 \mathrm{M}-\mathrm{NaCl}$ or $1 \%(\mathrm{w} / \mathrm{v})$ polyethylene glycol 4000 (Hopkin \& Williams) as solvent (Hignett et al., 1977).

Determination of enzyme pH optima. Buffer solutions at $\mathrm{pH} 4 \cdot 0$ and 5.6 were prepared with $0 \cdot 1 \mathrm{M}$-citric acid, adjusted with $10 \mathrm{M}-\mathrm{NaOH}$. Solutions at $\mathrm{pH} 7.5$ and 8.6 were prepared with $0.1 \mathrm{M}$-Tris, adjusted with $2 \mathrm{M}-\mathrm{HCl}$. The hydrolase activities (acid phosphatase, ribonuclease and deoxyribonuclease) of a typical preparation of extracellular fungal pigment were determined in these buffers, using the following methods. All enzyme assays were duplicated; the difference between duplicates was always less than $10 \%$.

Acid phosphatase. A $10 \%(\mathrm{w} / \mathrm{v})$ aqueous solution of 4-nitrophenyl disodium orthophosphate $(0 \cdot 1 \mathrm{ml})$, $0.1 \mathrm{ml}$ pigment (N50 at $5.0 \mathrm{mg} \mathrm{ml}^{-1}$ or $\mathrm{N} 75$ at $10.0 \mathrm{mg} \mathrm{ml}^{-1}$ ) and $1.0 \mathrm{ml}$ citrate buffer pH 5.5 were placed in a dialysis sac (8/32 Visking, Scientific Supplies, London, was used in all experiments) and dialysed against $5.0 \mathrm{ml}$ buffer at $30^{\circ} \mathrm{C}$. After $2 \mathrm{~h}$, a $1.0 \mathrm{ml}$ sample of diffusate was removed and replaced by $1.0 \mathrm{ml}$ fresh buffer. The sample was shaken with $0.1 \mathrm{ml} 10 \mathrm{M}-\mathrm{NaOH}$ after which the absorbance at $405 \mathrm{~nm}$ was determined. After $4 \mathrm{~h}$, a further $1.0 \mathrm{ml}$ sample of diffusate was similarly assayed. The same procedure was applied to reagent control solutions which contained $0 \cdot 1 \mathrm{ml}$ 4-nitrophenyl disodium orthophosphate solution and $1.1 \mathrm{ml}$ buffer. The results are expressed as the difference in absorbance at $405 \mathrm{~nm}$ between test and control solutions after $4 \mathrm{~h}$ incubation.

Tests on wheat-germ acid phosphatase $(\mathrm{BDH})$, with or without the use of dialysis sacs, showed that under the conditions described the results were not significantly affected by the presence of the membrane.

Ribonuclease. Reprecipitated yeast RNA (BDH; $100 \mathrm{mg}$ ) was dissolved in $10 \mathrm{ml}$ water and autoclaved $\left(15 \mathrm{~min}\right.$ at $\left.121^{\circ} \mathrm{C}\right)$ in a dialysis sac immersed in water. After cooling, the product was dialysed at $4{ }^{\circ} \mathrm{C}$ against several changes of water for $72 \mathrm{~h}$. The absorbance at $257 \mathrm{~nm}$ of the retained RNA solution was measured.

The RNA solution $(0.5 \mathrm{ml}), 0.1 \mathrm{ml}$ pigment (N50 at $5.0 \mathrm{mg} \mathrm{ml}^{-1}$ or $\mathrm{N} 75$ at $10.0 \mathrm{mg} \mathrm{ml}^{-1}$ ) and $0.5 \mathrm{ml}$ Tris buffer pH 7.5 were placed in a dialysis sac and dialysed against $5.0 \mathrm{ml}$ buffer at $37^{\circ} \mathrm{C}$ on a shaker. The absorbance of the diffusate at $257 \mathrm{~nm}$ in a $1.0 \mathrm{~cm}$ cell was determined after 2 and $4 \mathrm{~h}$. Reagent control sacs containing $0.5 \mathrm{ml}$ RNA solution and $0.6 \mathrm{ml}$ buffer were similarly treated. The results are expressed as the difference in absorbance at $257 \mathrm{~nm}$ between test and control solutions after $4 \mathrm{~h}$ incubation.

The results of tests on bovine pancreatic ribonuclease (BDH) by the method described above showed that virtually no further diffusion of enzymically degraded RNA occurred when the reaction was stopped by the addition of $0.1 \mathrm{vol} .50 \%(\mathrm{w} / \mathrm{v})$ trichloroacetic acid. Hence the presence of the membrane did not significantly affect the results of the assay.

Deoxyribonuclease. DNA (20 mg; prepared from yeast by the phenol method) was dissolved in $10 \mathrm{ml}$ water, placed in a dialysis sac immersed in water and autoclaved $\left(15 \mathrm{~min}\right.$ at $\left.121^{\circ} \mathrm{C}\right)$. After cooling, the sac was dialysed against several changes of water for $72 \mathrm{~h}$ at $4{ }^{\circ} \mathrm{C}$. The absorbance of the retained DNA solution was measured at $257 \mathrm{~nm}$ and the solution was used to detect deoxyribonuclease activity in pigment by the method described for ribonuclease measurement.

Phenoloxidase. Assays were carried out using the mixture of plant phenolics contained in NWED, or with catechol. (The results showed that the choice of substrate was not critical.) In the time-course experiments with NWED, phenoloxidase was assayed using reaction mixtures consisting of $0.2 \mathrm{ml}$ non-diffusible material (at $10 \mathrm{mg} \mathrm{ml}^{-1}$ ) and $0.1 \mathrm{ml} \mathrm{NWED}(30 \%, \mathrm{w} / \mathrm{v}$ ), made to $1.5 \mathrm{ml}$ with water. In the time-course experiments with basal medium, the enzyme was assayed using reaction mixtures consisting of $0.5 \mathrm{ml}$ non-diffusible material (at $10 \mathrm{mg} \mathrm{ml}^{-1}$ ) and $0.1 \mathrm{ml} 100 \mathrm{~mm}$-catechol, made to $2.0 \mathrm{ml}$ with water. In other phenoloxidase assays, $0.1 \mathrm{ml} 10 \mathrm{~mm}$-catechol (or $30 \%$, w/v, NWED) was added to samples of solution containing $0.25 \mathrm{mg}$ pigment, then made up to $1.5 \mathrm{ml}$ with water before incubation. The reagent controls contained the equivalent amount of water instead of enzyme solution. The absorbance of solutions was measured at $425 \mathrm{~nm}$ on mixing and again after incubation at room temperature for $4 \mathrm{~h}$. Results are given as the difference between the changes in absorbance of the test and control solutions. 
Stability of the enzyme activity of pigments during storage. $\mathrm{N} 75$ pigments from three re-isolates of clone $\mathrm{E}_{1}$ grown in October 1976 were filter-sterilized, assayed for enzyme activity and kept at $4{ }^{\circ} \mathrm{C}$ for 3 months. On removal from storage, the pigments were dialysed against several changes of water for $48 \mathrm{~h}$ at $4{ }^{\circ} \mathrm{C}$ before their enzyme activities were redetermined. Pigments obtained in March 1977 from a variety of re-isolates of clone $\mathrm{E}_{1}$ were filter-sterilized, assayed, and kept at $4{ }^{\circ} \mathrm{C}$ for 6 months before re-assay as above.

Time-course experiments. Three time-course experiments were set up with clone $\mathrm{E}_{\mathbf{1}}$ re-isolated in 1976: (1) $15 \times 40 \mathrm{ml}$ cultures with NWED were grown at $18{ }^{\circ} \mathrm{C}$ on an orbital shaker, and triplicate cultures were removed at intervals of 2 to $3 \mathrm{~d}$ over a period of $14 \mathrm{~d}$; (2) $8 \times 40 \mathrm{ml}$ cultures with NWED were grown as above, and pairs of cultures were removed at intervals over a period of $6 \mathrm{~d}$; (3) $30 \times 40 \mathrm{ml}$ cultures in basal medium alone were grown as above and sampled in triplicate at intervals of 2 to $3 \mathrm{~d}$ over a period of $35 \mathrm{~d}$. The mycelium in the pooled samples was filtered off, thoroughly washed with water and the dry weights were recorded. The culture fluids were concentrated under vacuum at $37^{\circ} \mathrm{C}$ to $0.25 \mathrm{vol}$. The concentrated fluids from experiment (1) were dialysed against several changes of water at $4{ }^{\circ} \mathrm{C}$ for $48 \mathrm{~h}$. Those from experi-

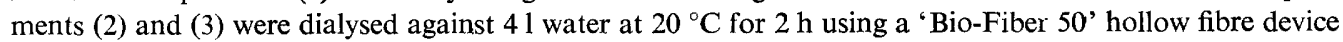
(Bio-Rad Laboratories). The results of the two methods did not differ significantly. The non-diffusible material was concentrated under vacuum at $37^{\circ} \mathrm{C}$ to $10 \mathrm{mg} \mathrm{m}^{-1}$. The precipitation step with ethanol was omitted. The enzyme activities of the non-diffusible material were assayed as previously described, using $0.2 \mathrm{ml}$ samples per test for the hydrolases. Phenoloxidase was assayed as described earlier.

Investigation of the virulence of four different clones of $V$. inaequalis, the respective enzyme activities in culture fluid and the effects of storage at $4{ }^{\circ} \mathrm{C}$ on clone $E_{1}$. Two re-isolates of clone $\mathrm{E}_{1}\left(\mathrm{E}_{1} 74\right.$ and $\left.\mathrm{E}_{1} 77\right)$ and three other clones $\left(\mathrm{W}_{2}, \mathrm{~W}_{8}\right.$ and $\left.\mathrm{W}_{36}\right)$ were each grown in six replicate $40 \mathrm{ml}$ shake cultures. The non-diffusible material produced by each isolate was prepared by concentrating the culture fluid to 0.25 vol., followed by dialysis for $48 \mathrm{~h}$ against several changes of water at $4{ }^{\circ} \mathrm{C}$. The retained material was concentrated to $9.0 \mathrm{mg}$ $\mathrm{ml}^{-1}$. Then 3 vol. ethanol at $-10^{\circ} \mathrm{C}$ were added to each preparation. After $3 \mathrm{~h}$ at $0{ }^{\circ} \mathrm{C}$, the precipitated whole pigments were collected by centrifugation and redissolved in $0.5 \mathrm{ml}$ portions of water at $0{ }^{\circ} \mathrm{C}$, overnight. Insoluble material was centrifuged off and the concentrations of the solutions were adjusted to $10 \mathrm{mg} \mathrm{ml}^{-1}$. Enzyme activities were then assayed using $0 \cdot 01 \mathrm{ml}$ samples.

The inoculum for use on test plants was prepared by gently, but exhaustively, washing the mycelium with water to remove adherent medium, then shaking in water to release the conidia. These were separated from the mycelium by filtration through muslin. The absorbance of each conidial suspension was adjusted to 0.02 (Kirkham, 1957) (except for clone $\mathrm{W}_{3}$, which was adjusted to 0.01) and applied to test plants as described below.

Inoculation of test plants. MM109 apple rootstocks were inoculated as described by Kirkham (1957), with certain modifications. Inoculum was sprayed on to individual plants at the rate of $6 \mathrm{ml}$ per 20 plants. A glass scent sprayer was used with compressed air (at $10 \mathrm{lbf} \mathrm{in}^{-2}, 69 \mathrm{kPa}$ ), at approximately $20 \mathrm{~cm}$ from the plant tips. The ambient temperature was maintained between 18 and $20^{\circ} \mathrm{C}$ whilst the room was kept at about $80 \%$ relative humidity. The inoculation chamber walls (made of double cotton muslin) were covered on the outer surfaces with aluminium foil to deflect sunlight and reduce evaporation, and were kept wet with recycled tap water. An overhead mist of distilled water (lasting 15 to $20 \mathrm{~s}$ ) was generated inside the chamber every $20 \mathrm{~min}$ during the $24 \mathrm{~h}$ infection period. The internal humidity was thereby maintained above $90 \%$ relative humidity as recorded by a hair hygrograph. Electrical conductivity measurements confirmed that this procedure kept the leaves wet continuously during the infection period.

\section{RESULTS AND DISCUSSION}

The production of non-diffusible extracellular material in NWED-augmented basal medium increased $5 \mathrm{~d}$ after inoculation, in parallel with the growth of the fungus. Growth was very poor in basal medium without NWED and very little extracellular material was produced (Fig. 1).

Enzymes detected in the non-diffusible fraction of culture filtrates showed $\mathrm{pH}$ optima at $4 \cdot 0,7 \cdot 5$ and $7 \cdot 5$ for acid phosphatase, ribonuclease and deoxyribonuclease, respectively. Activities were subsequently assayed at or near these values. Phenoloxidase was assayed in water at about $\mathrm{pH} 5 \cdot 0$, no significant $\mathrm{pH}$ change being observed during the reaction, and higher values being excluded by the onset of atmospheric oxidation. Activity was detected immediately after germination of the inoculum, but the initial high levels of activity (per g mycelium) declined rapidly within a day or two. As mycelial growth entered the exponential phase, the parallel increase in non-diffusible melanoprotein was accompanied by an 


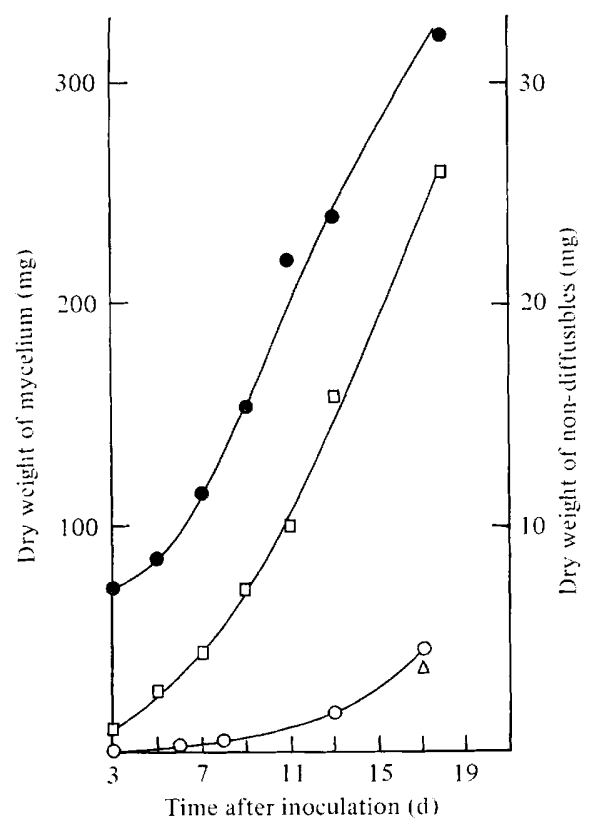

Fig. 1. Growth of $V$. inaequalis and production of non-diffusible material in $40 \mathrm{ml}$ shake cultures. -, Non-diffusibles in NWED culture fluid; $\square$, dry weight of mycelium in NWED culture; $\triangle$, non-diffusibles in basal culture fluid; $O$, dry weight of mycelium in basal culture. The term 'non-diffusible' includes a small proportion of polyphenolic material with the total melanoprotein, as mentioned in Methods.

increase in enzyme activity which, after some fluctuations, kept the specific activities approximately constant (Table 1). The results also show that the initial release of enzymes by conidia was approximately six times greater in the NWED augmented medium than in basal medium alone. Extracellular enzymes were produced without associated melanin by cultures grown in basal medium alone, but the total yields were very poor compared with those in the enriched medium. Even so, the enzyme activities per $g$ fungus after several days' growth in the two media were of similar magnitude.

Except for the phenoloxidase activity, which declined continuously, the enzyme activity of the isolated pigments (N75 fractions) remained constant during storage at $4{ }^{\circ} \mathrm{C}$ in sterile aqueous solution over a period of 1 to 2 weeks. However, after 3 months' storage the specific activities (in all but two cases) had increased significantly ( $\geqslant 20 \%$ ) above the original levels (Table 2). This effect indicated that inactive enzyme was slowly activated during storage. In contrast, further work with both N50 and N75 fractions showed that after 6 months storage many of the enzymes had activities close to or less than the original values, indicating that normal deterioration of protein eventually predominated (Table 3). Three of the 16 samples had lost significant $(\geqslant 20 \%$ ) amounts of activity, eight showed little apparent change $(\leqslant 20 \%)$ and only five still had activities considerably above those measured 6 months previously (in March 1977). Table 3 also shows a strong tendency for each activity to increase in one fraction and to decrease in the other. The strength of the bond between the melanin and the protein components of the fungal product was indicated by the lack of effect of dissociating agents, and the failure of the separation techniques employed to isolate protein. The evidence suggests that enzyme protein is tightly bound in the fungal pigment, but that cryptic activity is slowly revealed without total dissociation occurring.

The formation of complexes in mixtures of melanoprotein and polyelectrolytes in commercial ampholyte solutions was observed during electrophoresis. Gel electrophoresis 


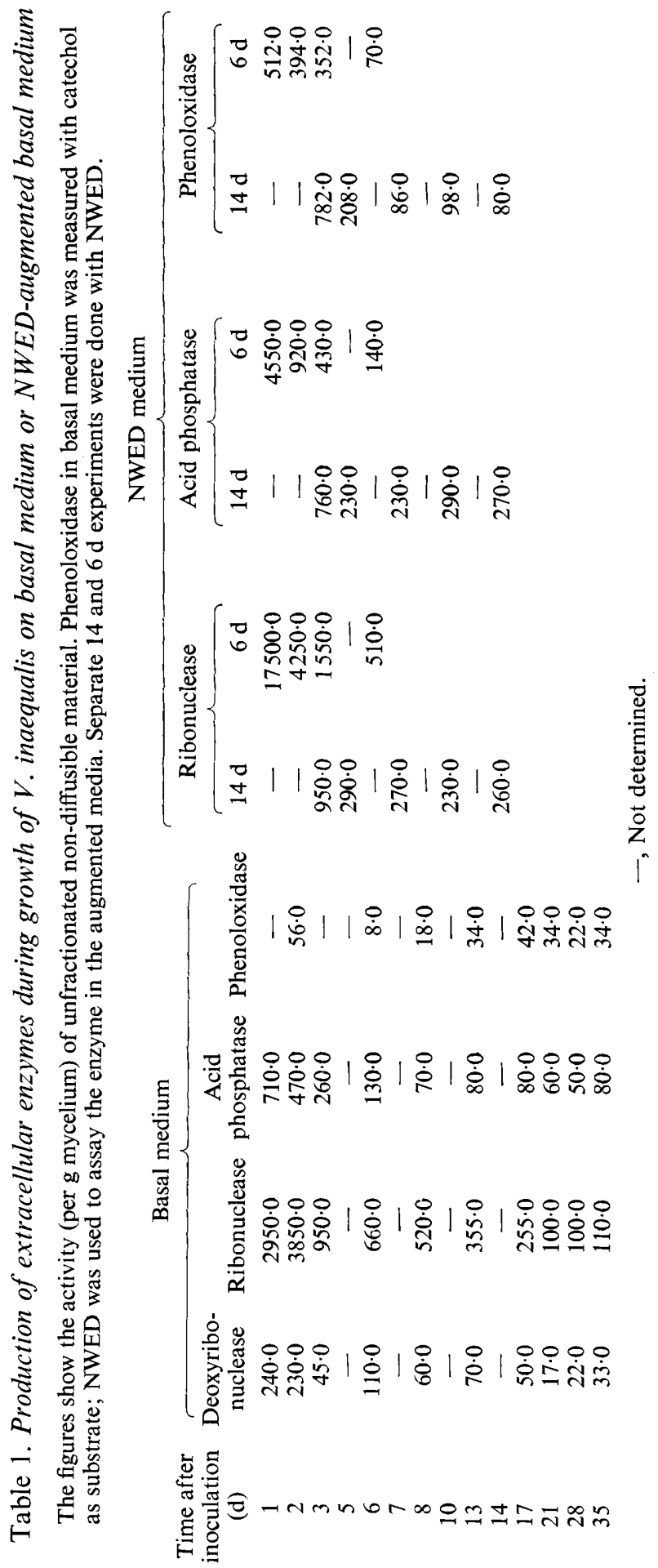




\section{Table 2. Stability of extracellular enzymes during storage at $4{ }^{\circ} \mathrm{C}$ for 3 months}

The specific activities are expressed as the difference in absorbance between sample and control solutions, per mg melanoprotein.

\begin{tabular}{|c|c|c|c|c|c|}
\hline \multirow[b]{2}{*}{ Pigment } & \multirow[b]{2}{*}{ Enzyme assayed } & \multirow[b]{2}{*}{$\begin{array}{l}\text { Date of } \\
\text { re-isolation }\end{array}$} & \multicolumn{3}{|c|}{ Specific activity } \\
\hline & & & $\begin{array}{c}\text { Date of culture } \\
\text { and 1st assay } \\
\text { Oct. } 1976\end{array}$ & $\begin{array}{l}\text { 2nd assay } \\
\text { Jan. } 1977\end{array}$ & $\begin{array}{l}\text { Percentage } \\
\text { change }\end{array}$ \\
\hline N75 & Acid phosphatase & $\begin{array}{l}1974 \\
1975 \\
1976\end{array}$ & $\begin{array}{l}0.98 \\
0.52 \\
0.81\end{array}$ & $\begin{array}{l}0.93 \\
1.52 \\
1.00\end{array}$ & $\begin{array}{r}-5 \\
+192 \\
+23\end{array}$ \\
\hline N75 & Ribonuclease & $\begin{array}{l}1974 \\
1975 \\
1976\end{array}$ & $\begin{array}{l}2 \cdot 58 \\
2 \cdot 34 \\
2 \cdot 88\end{array}$ & $\begin{array}{l}3 \cdot 46 \\
3 \cdot 30 \\
3 \cdot 36\end{array}$ & $\begin{array}{l}+34 \\
+41 \\
+17\end{array}$ \\
\hline N75 & Deoxyribonuclease & $\begin{array}{l}1974 \\
1975 \\
1976\end{array}$ & $\begin{array}{l}0 \cdot 39 \\
0 \cdot 34 \\
0 \cdot 44\end{array}$ & $\begin{array}{l}0.66 \\
0.68 \\
0.78\end{array}$ & $\begin{array}{r}+69 \\
+100 \\
+77\end{array}$ \\
\hline
\end{tabular}

Table 3. Stability of extracellular enzymes during storage at $4{ }^{\circ} \mathrm{C}$ for 6 months

The results are derived as in Table 2 .

\begin{tabular}{|c|c|c|c|c|c|}
\hline \multirow[b]{2}{*}{ Pigment } & \multirow[b]{2}{*}{ Enzyme assayed } & \multicolumn{4}{|c|}{ Specific activity } \\
\hline & & $\begin{array}{l}\text { Date of } \\
\text { re-isolation }\end{array}$ & $\begin{array}{c}\text { Date of culture } \\
\text { and 1st assay } \\
\text { Mar. } 1977\end{array}$ & $\begin{array}{l}\text { 2nd assay } \\
\text { Sept. } 1977\end{array}$ & $\begin{array}{l}\text { Percentage } \\
\text { change }\end{array}$ \\
\hline N50 & Acid phosphatase & $\begin{array}{l}1974 \\
1975 \\
1976 a \\
1976 b\end{array}$ & $\begin{array}{l}0.76 \\
0 \cdot 27 \\
0 \cdot 16 \\
0.08\end{array}$ & $\begin{array}{l}0 \cdot 81 \\
0 \cdot 36 \\
0 \cdot 175 \\
0 \cdot 115\end{array}$ & $\begin{array}{r}+7 \\
+33 \\
+75 \\
+44\end{array}$ \\
\hline N75 & Acid phosphatase & $\begin{array}{l}1974 \\
1975 \\
1976 a \\
1976 b\end{array}$ & $\begin{array}{l}0 \cdot 24 \\
0 \cdot 26 \\
0 \cdot 13 \\
0 \cdot 16\end{array}$ & $\begin{array}{l}0 \cdot 205 \\
0 \cdot 22 \\
0 \cdot 10 \\
0 \cdot 14\end{array}$ & $\begin{array}{l}-15 \\
-15 \\
-23 \\
-12 \cdot 5\end{array}$ \\
\hline N50 & Ribonuclease & $\begin{array}{l}1974 \\
1975 \\
1976 a \\
1976 b\end{array}$ & $\begin{array}{l}2 \cdot 39 \\
2 \cdot 35 \\
3 \cdot 93 \\
3 \cdot 13\end{array}$ & $\begin{array}{l}1 \cdot 88 \\
0 \cdot 28 \\
4 \cdot 90 \\
2 \cdot 92\end{array}$ & $\begin{array}{r}-21 \\
-88 \\
+25 \\
-7\end{array}$ \\
\hline N75 & Ribonuclease & $\begin{array}{l}1974 \\
1975 \\
1976 a \\
1976 b\end{array}$ & $\begin{array}{l}1 \cdot 76 \\
2 \cdot 85 \\
2 \cdot 21 \\
2 \cdot 01\end{array}$ & $\begin{array}{l}2 \cdot 04 \\
3 \cdot 34 \\
2 \cdot 70 \\
2 \cdot 21\end{array}$ & $\begin{array}{l}+16 \\
+17 \\
+22 \\
+10\end{array}$ \\
\hline
\end{tabular}

of $\mathrm{N} 75$ or $\mathrm{N} 50$ in $1 \%(\mathrm{w} / \mathrm{v})$ Ampholine $\mathrm{pH} 3$ to 5 gave four major bands, which were cut out and eluted with water. On re-running these separately in the same system, patterns similar to the original were produced in each case, suggesting that complexes had formed. This was confirmed by using the alternative $\mathrm{pH}$ gradient system, which gave a single band with the melanoproteins. Further confirmation was afforded by mixing the melanoprotein $(0.5 \mathrm{mg}$ in $0.05 \mathrm{ml}$ water) with $5.0 \mu \mathrm{l} 40 \%$ (w/v) Ampholine $\mathrm{pH} 3$ to 5 or $\mathrm{pH} 5$ to 8 before electrophoresis on the mixed-acid gel (Fig. 2). In the latter case, the resulting sharply resolved bands lying between $\mathrm{pH} 3 \cdot 3$ and $\mathrm{pH} 4 \cdot 3$ were well below the lower limit of the Ampholine $\mathrm{pH}$ range 5 to 8 , the pattern being different from that given by the low $\mathrm{pH}$ range Ampholine. Similar effects were observed during sucrose density gradient experiments. These effects showed that the melanoprotein possessed considerable reversible complexing capacity. This behaviour is similar to that of humic acids and proteins noted by Righetti 


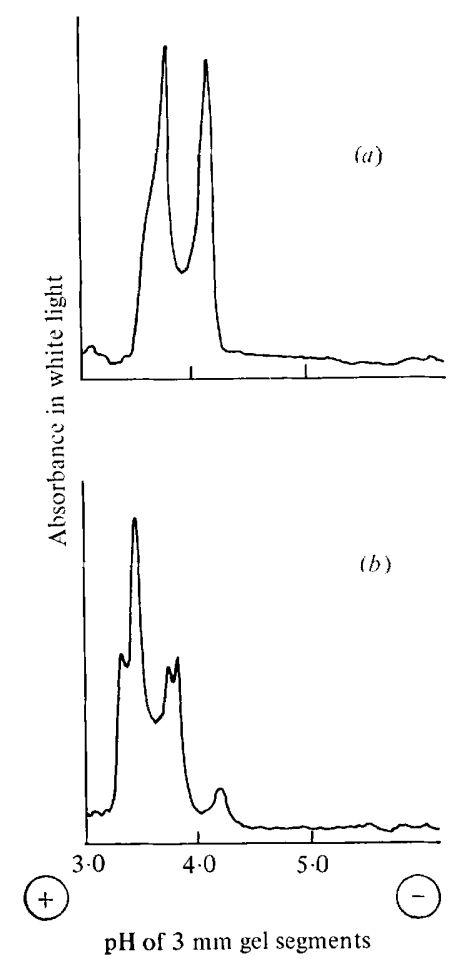

Fig. 2. Complex formation during polyacrylamide gel electrophoresis on a mixed-acid $\mathrm{pH}$ gradient. The melanoprotein $(0.5 \mathrm{mg} \mathrm{N} 75$ in $50 \mu \mathrm{l}$ water) was mixed before loading with $5 \mu 140 \%(\mathrm{w} / \mathrm{v})$ Ampholine pH 5 to $8(a)$ or $\mathrm{pH} 3$ to $5(b)$.

et al. (1977), and contrasts with the apparent stability of the melanin-protein bond discussed previously.

Clone $\mathrm{E}_{1}$ of the fungus is comparatively stable, retaining colony morphology and some declining virulence over a period of 2 to 3 years in contrast with other clones which lose virulence in a matter of weeks, in culture. Enzyme levels in the material isolated from culture filtrates of growths started at intervals of 6 months are unpredictable, but a pronounced long-term trend is superimposed upon this short-term instability. Table 4 shows the differences in enzyme activity of the pigments produced by a set of re-isolates of clone $E_{1}$ cultured simultaneously. The total and specific activities of the hydrolases were not reproduced by re-isolates cultured at intervals of several months. Consistent differences can be seen, however, between the activities of enzymes in cultures of re-isolates taken 4 or more years apart. Except for phenoloxidase, the total and specific activities of enzymes produced by the oldest (1970) re-isolate were, with one marginal exception, much lower than those of the younger re-isolates, in many cases by a factor greater than 10 . In contrast, the specific activity of the phenoloxidase produced by the 1970 re-isolate was considerably greater than that of the more recent re-isolates. The 1970 re-isolate had virtually lost the capacity to sporulate in culture, and was avirulent. An inverse relationship between virulence and phenoloxidase production is also shown (for two other isolates of $E_{1}$ ) in Table 5.

Thus loss of virulence during storage is associated with decreased ribonuclease, deoxyribonuclease and acid phosphatase production in subsequent cultures, and an increase in the specific activity of phenoloxidase. Phenoloxidase has been implicated in disease resistance generally (Kljajič et al., 1964; Tomiyama \& Stahmann, 1964; Stahmann \& Demorest, 1973). The role of phenoloxidase in disease is usually correlated with the generation of 
Table 4. Production of extracellular enzymes by re-isolates of clone $E_{1}$ after storage under oil at $4{ }^{\circ} \mathrm{C}$

The figures show the activities per $\mathrm{g}$ mycelium after $14 \mathrm{~d}$ growth; specific activities (per mg pigment) are given in parentheses.

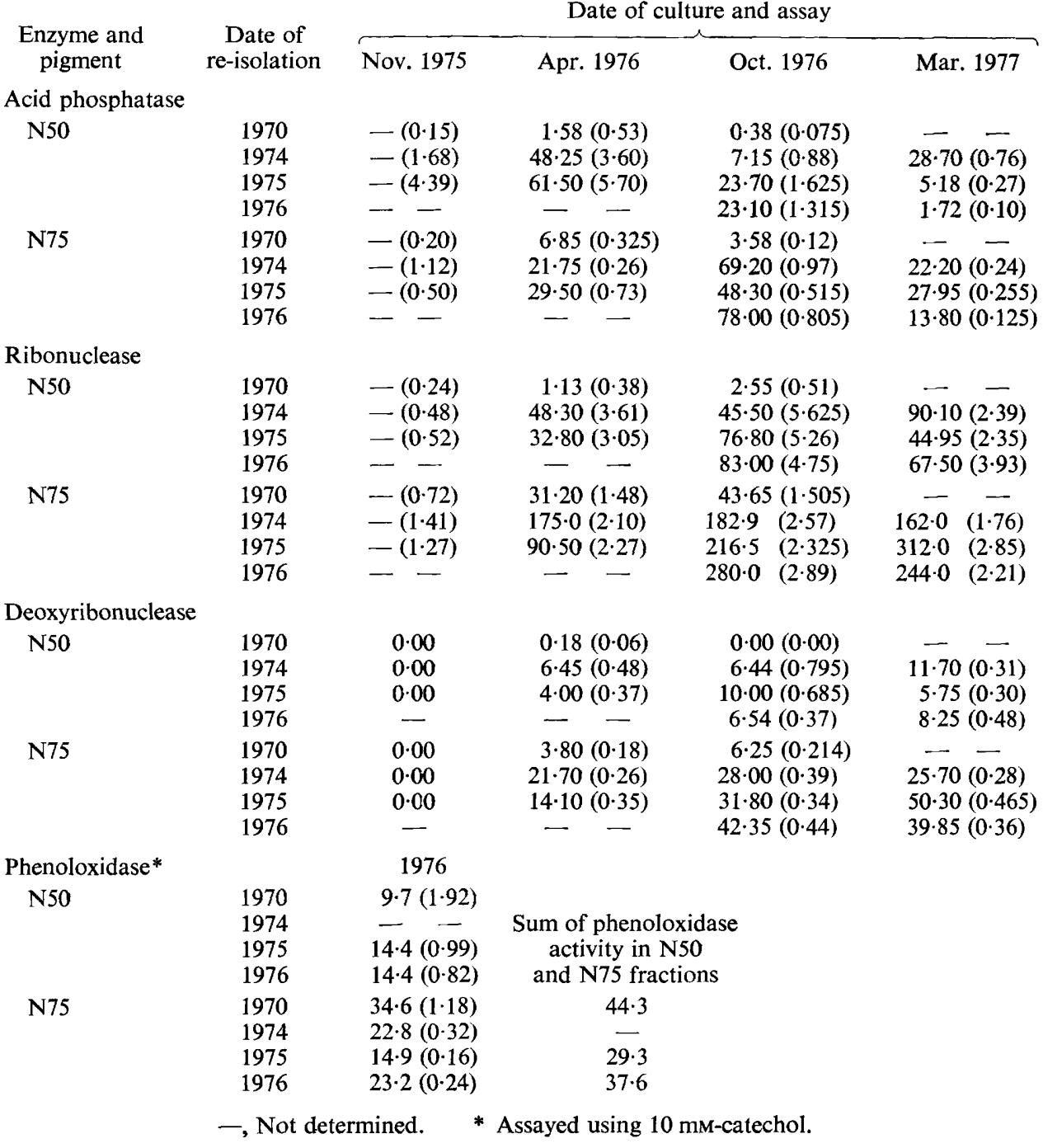

phenolic oxidation products toxic to the pathogen. Production of extracellular phenoloxidase by $V$. inaequalis would tend to enhance this effect, thereby inhibiting its growth. The fungus would also be deprived of phenolic substrates, which would hinder its capacity to synthesize melanoprotein which is active in the apple scab disease (Hignett \& Kirkham, 1967; Hignett, 1973).

In view of the generally observed changes in virulence of isolates of $V$. inaequalis during long-term storage and the variation in the associated enzyme activity described previously, an attempt was made to correlate the two effects. The results show that the different clones and isolates varied widely in virulence, but no general correlation was seen between the enzyme activities generated in culture and the virulence of the different clones on MM109 apple rootstocks (Table 5). 
Table 5. Virulence of $V$. inaequalis on MM109 apple rootstocks, and the enzyme activity of melanoprotein isolated from the cultures used to provide the inoculum

Phenoloxidase was assayed with NWED. Specific activities are expressed per $\mathrm{mg}$ unfractionated melanoprotein.

$\begin{array}{ccccc}\text { Clone } & \begin{array}{c}\text { Phenol- } \\ \text { oxidase }\end{array} & \begin{array}{c}\text { Acid } \\ \text { phosphatase }\end{array} & \begin{array}{c}\text { Ribo- } \\ \text { nuclease }\end{array} & \begin{array}{c}\text { Mean no. } \\ \text { of lesions } \\ \text { per plant }\end{array} \\ \mathrm{E}_{1} 74 & 2.68 & 1.97 & 3.70 & 0.50 \\ \mathrm{E}_{1} 77 & 1.95 & 1.86 & 3.60 & 18.80 \\ \mathrm{~W}_{2} & 0.98 & 3.03 & 3.20 & 2.20 \\ \mathrm{~W}_{8} & 1.25 & 0.05 & 0.0 & 11.60 \\ \mathrm{~W}_{36} & 1.25 & 0.73 & 0.70 & 2.00\end{array}$

The evidence shows that the levels of enzyme activity released into culture fluid correlate with changes in virulence of clone $E_{1}$ during long-term storage, but do not indicate the comparative levels of virulence of different clones.

Thanks are due to Miss S. C. Wilson for technical assistance and to Dr D. S. Kirkham for the provision of source cultures.

\section{REFERENCES}

HignetT, R. C. \& Kirkham, D. S. (1967). The role of extracellular melanoproteins of Venturia inaequalis in host susceptibility. Journal of General Microbiology 48, 269-275.

HignetT, R. C. (1973). The absorption of silverlabelled fungal pigment by bacterial and apple ribosomes. Journal of General Microbiology 79 , 95-101.

Hignett, R. C., Carder, J. H. \& Smith, A. R. W. (1977). Origin and characteristics of Venturia inaequalis melanoproteins active in the apple scab disease. Journal of General Microbiology 102, 207-210.

KIRKham, D. S. (1957). Relationships between cultural characteristics and pathogenicity in Venturia inaequalis and Venturia pirina. Journal of General Microbiology 16, 360-373.

Kluajič, R., Babovič, M. \& PlesniČar, M. (1964). Peroxidase and polyphenoloxidase activity and absorption of ${ }^{32} \mathrm{P}$ in the leaves of some varieties of strawberries infected with strawberry crinkle virus. In Host-Parasite Relations in Plant Pathology, pp. 69-72. Edited by Z. Kiraly \& G. Ubrizsy. Budapest: Research Institute for Plant Protection.

Righetti, P. G., Gianazza, E., Brenna, O. \& GaLANTE, E. (1977). Isoelectric focussing as a puzzle. Journal of Chromatography 137, 171-181.

Stahmann, M. A. \& Demorest, D. M. (1973). Changes in enzymes of host and pathogen with special reference to peroxidase interaction. In Fungal Pathogenicity and the Plant's Response, pp. 405-422. Edited by R. J. W. Byrde \& C. V. Cutting. New York: Academic Press.

Stenman, U.-F. \& GräSBECK, R. (1972). Gradients for isoelectric focussing at low $\mathrm{pH}$. Biochimica et biophysica acta 286, 243-251.

Tomiyama, K. \& Stahmann, M. A. (1964). Alteration of oxidative enzymes in potato tuber tissue by infection with Phytophthora infestans. Plant Physiology 39, 483-490. 